\title{
DOCUMENTS.
}

\section{EIGHTY-GUN SHIPS.}

\author{
(Contributed by SIR J. K. LAUghTON.)
}

\author{
Excerpt from a letter from Vice-Admiral Thomas Mathews, Com- \\ mander-in-Chief of the Fleet in the Mediterranean, to the Duke of \\ Newcastle; I 7 Feb., I 743 O.S.
}

“. . . . Ships one, two and three years off the ground will never come up with clean ships at most not above two months, nor can ships which cannot make use of their lower tires of guns, though they mount 90 and 80 guns, do the duty expected (by the ignorant) against the 74 and 64 gun ships of France who can fight theirs. The Reasons are obvious: there is no proportion of metal, our 8o-gun ships having but 12 and 6 pounders whereas some of the Enemy's 74-gun ships carry 40, I 8 and 9 pounders (as Rear-Admiral Rowley found by experience), the rest of them 32, I8 and 9 ; their ships of 64 guns have 24,18 and 9 pounders, which makes even them better men of war than our 8o-gun ships that cannot make use of their lower tires, which they will very seldom be able to do. Neither is there any proportion in their Number of Officers and men. M. de Court has I 5 officers in his ship, I have 7. He has 900 to 1,000 men : I have 780 when full manned. All the rest of the ships are in proportion. I have now but two ships of 90 and three of 80 guns that can make use of their lower tires of guns if it blows a cap full of wind. Admiral Rowley in tho Barfleur was obliged to run out his weather guns, to lash 30 tuns of water to windward, and to cut away his lee anchor before he could do it; the Princess Caroline took in the water so fast, that her Captain, whose conduct and behaviour proves him to be a very good officer, was obliged to scuttle the deck to vent the water; she took it in so fast. As for the rest of them, they can scarce haul up a port; the Chichester hauled up but her two aftermost, but was obliged soon to lower them ; as for the rest of her ports, they were caulked in when she first fitted out, and have never been opened since, nor will they ever be, except in a Mill Pond. She is one of the 8o-gun ships Mr. Vernon writ against, if I mistake not; the Torbay is another. I will venture to affirm that it would have been more for His Majesty's Service (abstracted from good husbandry) that she had been burnt, than to have repaired her at such a monstrous expence; a commanding officer has a bad time of it with such a number of bad men-of-war, and those ill-manned, abstracted from their foulness."

\section{“THE MARINER'S MIRROUR."}

(Contributed by Mr. D. B. Surtu).

"THE Mariner's Mirrour," as has already been stated in this journal, was the title chosed by Ashley for his English translation of Waghenaer's "Speighel der Zeevaerdt," and the present cover of the journal repro-

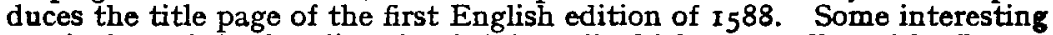
particulars of the first "Mariner's Mirror," which were collected by Pepys, and are to be found in the Pepys MSS, are here reproduced from a transcription in the Admiralty Library. 
"Our coasts so well known" (i.e., by foreigners), Pepys writes, " that till Seller fell into it we had very few draughts even of our own coasts printed in England, but all our English mariners, even upon our own coasts as well as elsewhere saild by the Wageñer printed by the Dutch, which they generally use to this very day.

"And if we allow them to be our best guides, why should they not be the same to the French who also generally sail by the very same Waggener, printed by the Dutch at Amsterdam, An. I669, in French ?"

These remarks were called for by the presence of the French fleet off our coasts in I692, and Pepys was sufficiently interested in Waghonaer to collect the following notes :

"It appears that the first edition of the first part of Waggener was printed in ${ }_{5} 8_{3}$ in Dutch, was presented to Q. Eliz. and her Privy Council in the year 1586 or before, by the Dutch Embassadr, and approv'd and encourag'd by them to be translated into some more universal language (which by Waggener's Epistle, I 586 , seems to have been then done by him into Latin-Quære ?) And this [ then ?] by one Anto. Ashley (ancestor of $\mathbf{m y}$ Ld. Shaftsbury) at the instance of Sr. C. Hatton, Ld. Chancellor, and was in doing the time of the Spanish Preparations against us, and ours against them, An. 1587, and publish'd within 3 months after the Defeat of the Spanish Armada, which was in July, 1588: And Ashley's Dedicatory Epistle, dated zoth of October, following, in which he declares not only the welcomeness of this work to all and especially our English Marriners, but the little fear they had of any ill consequence to us of exposing to the world the Draught of our Coasts, from their encouraging the translating of it into Latin, as well as causing it to be done into English, and this not only when they were expecting and preparing for the approaches of this great Enemy, but even after so late an experiment how much the Defeat of the Spaniards was to be imputed to the Ignorance of our Coasts, and this also notwithstanding, he observes at the same time, that the malice of the comon enemy of God and Man (meaning the Spaniard) did even then after that defeat daily encrease and come to height, the Author reckoning the publishing this work as one means of our Defence, and the Chancellor's comd. for his translating of this Book (both parts of which were now publishd by Waggener, and consequently our whole Coasts and River of Thames expos'd), a manifestation of his Zeal for this common good, grounded (I suppose) upon the need which our Mariners themselves stood in of this Help; And this I the rather think, from its being presented to the Queen and Council by the Ld. Adml. himself : and the truth of this Dutchman's in particular from their Embassr. owned by Ashley's translating it with contradiction. To which is further to be added that Ashley is not contented to translate Waggener's Mapps, but pretends upon advice with the best experienced to have mended them in many places, and left blanks in the Sea for any future amendment. And probably $(Q$ : whether so or not) most of those amendments of his must respect our own coasts. And yet, notwithstanding all the labours of this Gentleman's of having his Plates cut on purpose in England, and all his pretended Amendments therein, and his care (according to his words in his title page) in fitting this his work with necessary Additions for the use of Englishmen, yet the subsequent Editions of the Dutch Waggener translated and printed by the Dutch themselves in English, with their own Dutch plates, have from time to time to this prevail'd among us English (as the same in French has done among the French) till Seller fell to work and made some improvements therein but all before 1675 . And it is to be remembered also that the Dutch were at the same when Waggener published this work for the laying down more plainly than ever before their own, and our Coasts under the greatest difference with and distresses from Spain, and we engaged in their Assistance. Note also that Ashley for the better recommending his Book observes in his Title page, that therein may be understood the Exploits lately atehiev'd by the Ld. Adml. with the Queen's Navy (meaning 
that against the Spanish Armada) and the former Services of Sr. Fran: Drake's."

Pepys quite perceived the financial difficulties which such an enterprise in English would have to surmount and notes, "'Tis fit to consider the unreasonableness that any but a Prince should ever bear the charge which is necessary for the taking good description of Places, and making of true Sea Charts: And therefore never was done till now that Collins is at work under the Encouragement of the King."

It may be noted in passing that the Collins and Seller referred to by Pepys are Captain Greenville Collins and John Seller respectively, and that the Admiralty Library possesses copies of the works of both of these famous cartographers who were Pepys' contemporaries.

(To be continued).

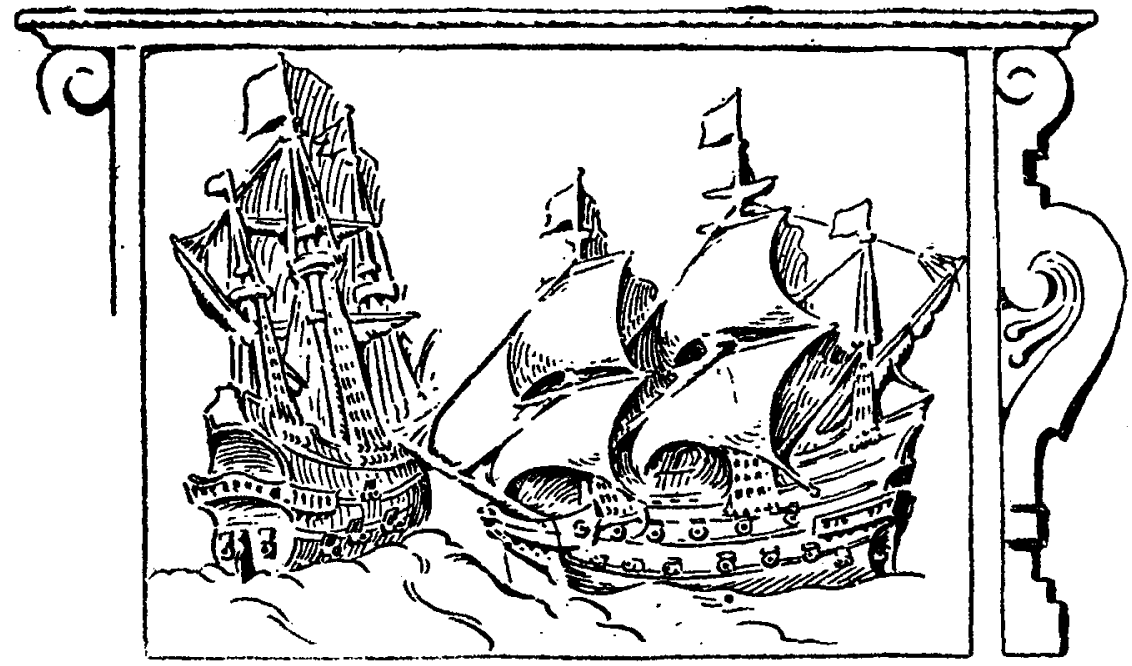

